\title{
The Effect of Dipel and Spruzit Biopesticides on Metcalfa pruinosa (Say, 1830) (Homoptera: Flatidae)
}

\author{
Temel Gokturk
}

Department The University of Artvin Coruh, Faculty of Forestry, Department of Forest Entomology and Protection, Artvin / Turkey

\begin{abstract}
Metcalfa pruinosa (Say) is one of the important harmful insect species of the coastal areas of Eastern Black Sea Region. This insect poses a danger by feeding on the juices of hundreds of plants in the region. This study was designed to create a fight strategy against M.pruinosa, which has posed an intense danger in Artvin - Kemalpassa in recent years, and the effect of Spruzit Neu and Dipel biopesticides on the nymphs and adults of the insect was investigated, and the applicability of these biopesticides was revealed. The study was conducted in the summer season of 2016 when the nymphs and adults of the insect are abundant in the region. In in vitro conditions, the Spruzit Neu (Pyrethrum) and Dipel DF (Bacillu thuringiensis) biopesticides were sprayed at different doses (DiPel ${ }^{\circledR}$ DF BT 100gr / 100lt, Dipel ${ }^{\circledR}$ DF BT 300gr / 100lt, Dipel ${ }^{\circledR}$ DF BT 500gr / 100lt ve Spruzit ${ }^{\circledR}$ $\mathrm{Neu}$ ) on the nymphs and adults of the insect. The adults and nymphs were checked with 2-day intervals, and the results were assessed according to the One-Way Variance Analysis (ANOVA) and the Duncan Test. It was determined that the most effective applications for the nymphs were Dipel DF 300gr/100lt and 500gr/100lt. It was also determined that the most effective applications for the adult individuals were Spruzit Neu 600ml/100lt and Dipel DF 500gr/100lt doses. The highest death rates in the nymphs were determined in Spruzit Neu 600ml/100lt dose as 72,5\%; and in Dipel DF dose as $80 \%$. These rates were determined in Pyrethrum 600 $\mathrm{ml} / 100 \mathrm{lt}$ dose as $78 \%$, and in Dipel DF $500 \mathrm{gr} / 100 \mathrm{lt}$ dose as $75 \%$. As a conclusion, it was determined that both biopesticides are influential on the nymphs and adults of M.pruinosa. However, it was also determined that the fight will be more influential in the nymph period of the insect.
\end{abstract}

Keywords-Biopesticides, Spruzit, Dipel, Turkey.

\section{INTRODUCTION}

The homeland of Metcalfa pruinosa (Say, 1830) is North America (Homoptera: Flatidae), and is an agricultural harmful insect causing damages in more than 200 plant www.ijeab.com species mainly on citrus fruits [1, 2]. This insect has caused harms in a great deal of Europe for many years [3, $4,5]$. It was first detected in citrus fruits in orchards in Turkey in 2003 in Izmir [6]. M. pruinosa started to cause important harms in Trabzon dates, figs, walnuts and apple trees and mostly in kiwi fruit in recent years in the Eastern Black Sea Region. The nymphs and adults feed on the juice of these trees and cause direct harms, or the sweet substance they secrete in intense populations cause fumagine $[7,8,9,10]$. When it exists in hosts together with Ricania simulans, which is another harmful insect in the region, the severity and rate of the harm increases. It has been understood in the studies conducted in other countries that the potential of the spread of this insect is more due to its strong ability in flying and the variety of the host plants $[11,12]$. No studies were detected in the literature on the fight against this insect in our country. The studies conducted on the spread, hosts, biology and fight against this insect are also rare.

In the light of the technological developments in our present day, successful results have been reported on the fight against harmful insects in agriculture. However, the organic tea growth in and around the coastal areas of Rize and Artvin cities where M.pruinosa causes great harms limits the fight against it. Since chemical fight is not possible in the region, it has become inevitable to search for alternative substances to fight against this harmful insect. Using plant-based insecticides and bioinsecticides in organic agricultural areas is one of the effective methods. Azadirachtin, pyrethrum, rotenone, nicotine, ryania, sabadilla, quassine are among the most frequently used plant-based insecticides [13]. The most frequently used bioinsecticide is Bacillus thuringiensis [14, 15, 16, 17]. In the present study, which was conducted in Artvin, the effect of Pyrethrum (Spruzit Neu) and Dipel (B.thuringiensis) biopesticides on the nymphs and adults of M.pruinosa was investigated and its applicability was revealed. 


\section{MATERIAL AND METHOD}

The material of the study consists of the nymphs and adults of M.pruinosa, Cyperus, tulle curtain cages, and biopesticides. In order to create the medium in which the insect lives in in vitro conditions, a humidifying machine was also made use of. In this study, which was conducted in the summer season of 2016, the commercial name and usage dose of the medications used in the applications against the nymphs and adults of the insect, the number of the cages, and the number on the alive nymphs and adults in the cages are given in Table 1.

Table.1: Sampling organization

\begin{tabular}{|c|c|c|c|}
\hline Trade name of the pesticide $\&$ dose usage & $\begin{array}{c}\text { Number of } \\
\text { cages }\end{array}$ & $\begin{array}{c}\text { Number of } \\
\text { nymphs/cages }\end{array}$ & Number of adults/cages \\
\hline Pyrethrum (Spruzit Neu 150ml/100lt) & 10 & 20 & 20 \\
\hline Pyrethrum (Spruzit Neu 300ml/100lt) & 10 & 20 & 20 \\
\hline Pyrethrum (Spruzit Neu 600ml/100lt) & 10 & 20 & 20 \\
\hline $\begin{array}{l}\text { Bacillus thuringiensis (Dipel DF } \\
\text { 100gr/1001t) }\end{array}$ & 10 & 20 & 20 \\
\hline $\begin{array}{l}\text { Bacillus thuringiensis (Dipel DF } \\
300 \mathrm{gr} / 1001 \mathrm{t})\end{array}$ & 10 & 20 & 20 \\
\hline $\begin{array}{l}\text { Bacillus thuringiensis (Dipel DF } \\
500 \mathrm{gr} / 100 \mathrm{lt} \text { ) }\end{array}$ & 10 & 20 & 20 \\
\hline
\end{tabular}

The study was conducted in 10 repetitions in in vitro conditions, and kiwi seedlings that were taken into pots were covered with tulle curtain in 20x20X40 cm size. 20 nymphs were placed in these cages by considering the biology of the insect in early July when the nymph population is intense, and the biopesticides were applied with spray method in the predefined doses.

Following the biopesticides, 5 controls were made in every 2 days, and the alive and dead individuals were counted. Similarly, the adults were collected in late August and brought to laboratory and were subjected to the same practice. In each application, 1 (one) pot was assigned as the control application with pure water. The results obtained in the trials were analyzed with statistical methods.

\section{Statistical Analyses}

The SPSS 15.0 Package Program complying with Windows 10 was used in the analyses. In order to determine the effect of the doses of the biopesticides applied on the nymphs and adults of M.pruinosa, the One Way Variance Analysis (ANOVA) was applied. The Duncan Test was made use of to determine the most effective biopesticide.

\section{FINDING}

In the laboratory works, it was observed that all the doses were effective at certain levels on the nymphs and adults of M.pruinosa. It was determined that there are significant differences among the 6 different applications that were used against the nymphs of M.pruinosa (Tablo 2).

As a result of the analyses of the data obtained with the biopesticides against the nymphs of M.pruinosa, it was observed that the effects of Pyrethrum were at the same level in $150 \mathrm{ml} / 100 \mathrm{lt}$ dose, and $300 \mathrm{ml} / 1001 \mathrm{t}$ dose. As a result of the analyses, the effects of Pyrethrum in 600ml/100lt dose and Dipel DF in 100gr/100lt dose were similar. As a result of the statistical analysis, it was determined that all the doses of Dipel DF were similar.

Table.2: Oneway ANOVA Results showing the effects of the pesticides and the doses applied on the nymphs and adults of M.pruinosa

\begin{tabular}{cccc}
\hline $\begin{array}{c}\text { Period of } \\
\text { development }\end{array}$ & $\begin{array}{c}\text { The degree } \\
\text { of freedom } \\
\text { (DOF) }\end{array}$ & F value & $\begin{array}{c}\text { Significance } \\
\text { level }(\mathrm{p})\end{array}$ \\
\hline Nymphs & 5 & 18.765 & .001 \\
Adults & 5 & 69.002 & .001 \\
\hline
\end{tabular}

As a result of the analyses made on the data obtained from the biopesticide applications on the adults of M.pruinosa, it was determined that although the efficacy of the Pyrethrum in $150 \mathrm{ml} / 1001 \mathrm{t}$ dose was different from the other doses, the efficacies of Pyrethrum in $300 \mathrm{ml} / 1001 \mathrm{t}$ dose and Dipel DF in 100gr/100lt dose were similar to each other.

It was also observed that Dipel DF in 300gr/100lt and $500 \mathrm{gr} / 1001 \mathrm{t}$ dose and Dipel DF in 500gr/1001t, Pyrethrum in $600 \mathrm{ml} / 1001 \mathrm{t}$ dose were effective at the same rate.

It was found that the most effective applications for nymphs were Difel DF 100 gr/100 lt, Difel DF 300 gr/100 1t, Difel DF $500 \mathrm{gr} / 100 \mathrm{lt}$; and for the adults, the most effective applications were found to be Pyrethrum 600ml/100lt and Dipel DF 500gr/100lt applications (Table 3). 
Table.3: Effects of the pesticides and the doses applied on the nymphs and adults of M.pruinosa

\begin{tabular}{|c|c|c|c|c|}
\hline \multirow[b]{2}{*}{ Trade name of the pesticide $\&$ dose usage } & \multicolumn{2}{|c|}{ Nymph } & \multicolumn{2}{|c|}{ Adults } \\
\hline & Mean & $\begin{array}{l}\text { Standard } \\
\text { deviation }\end{array}$ & Mean & $\begin{array}{l}\text { Standard } \\
\text { deviation }\end{array}$ \\
\hline Pyrethrum (Spruzit Neu 150ml/100lt) & $14.6^{\mathrm{c}}$ & \pm 1.3 & $10.9^{\mathrm{d}}$ & \pm 1.1 \\
\hline Pyrethrum (Spruzit Neu 300ml/100lt) & $15.1^{\mathrm{c}}$ & \pm 1.3 & $14.8^{\mathrm{c}}$ & \pm 1.2 \\
\hline Pyrethrum (Spruzit Neu 600ml/100lt) & $17.9^{\mathrm{b}}$ & \pm 1.3 & $18.8^{\mathrm{a}}$ & \pm 0.9 \\
\hline $\begin{array}{l}\text { Bacillus thuringiensis (Dipel DF } \\
\text { 100gr/100lt) }\end{array}$ & $19.1^{\mathrm{b}, \mathrm{a}}$ & \pm 0.8 & $15.7^{\mathrm{c}}$ & \pm 1.2 \\
\hline $\begin{array}{l}\text { Bacillus thuringiensis (Dipel DF } \\
\text { 300gr/100lt) }\end{array}$ & $18.4^{\mathrm{a}}$ & \pm 0.6 & $18.0^{\mathrm{b}}$ & \pm 1.0 \\
\hline $\begin{array}{l}\text { Bacillus thuringiensis (Dipel DF } \\
\text { 500gr/100lt) }\end{array}$ & $18.7^{\mathrm{a}}$ & \pm 0.5 & $18.5^{\mathrm{b}, \mathrm{a}}$ & \pm 0.9 \\
\hline
\end{tabular}

As a result of the application against the nymphs of M.pruinosa, it was determined that the effect rates of Pyrethrum were $49.5 \%$ in $150 \mathrm{ml} / 100 \mathrm{lt}$ dose; $59.2 \%$ in $300 \mathrm{ml} / 100 \mathrm{lt}$ dose; and $72.5 \%$ in $600 \mathrm{ml} / 1001 \mathrm{t}$ dose. The effect rates of Dipel DF were $55.4 \%$ in $100 \mathrm{gr} / 100 \mathrm{lt}$ dose; $70.5 \%$ in $300 \mathrm{gr} / 100 \mathrm{lt}$ dose; and $80 \%$ in $500 \mathrm{gr} / 100 \mathrm{lt}$ dose.

As a result of the application against the adults of M.pruinosa it was determined that the effect rates of
Pyrethrum were $40.8 \%$ in $150 \mathrm{ml} / 100 \mathrm{lt}$ dose; $54.5 \%$ in $300 \mathrm{ml} / 100 \mathrm{lt}$ dose; and $65 \%$ in $600 \mathrm{ml} / 100 \mathrm{lt}$ dose. The effect rates of Dipel DF were $49.4 \%$ in $100 \mathrm{gr} / 1001 \mathrm{t}$ dose; $62.8 \%$ in $300 \mathrm{gr} / 1001 \mathrm{t}$ dose; and $75 \%$ in $500 \mathrm{gr} / 1001 \mathrm{lt}$ dose (Figures 1-2). After the applications, the highest death rates in both biopesticides were observed on the $2^{\text {nd }}$ and $4^{\text {th }}$ days.
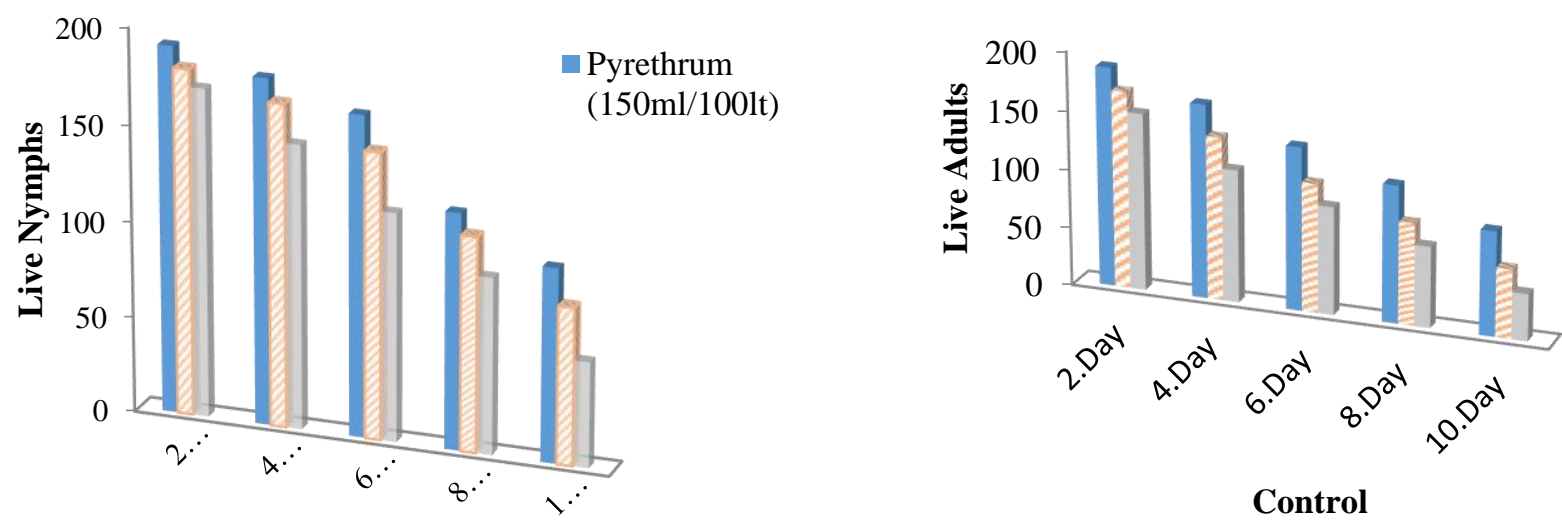

Control

Control

Fig.1: The effectiveness of different doses of Pyrethrum on the nymphs and adults.

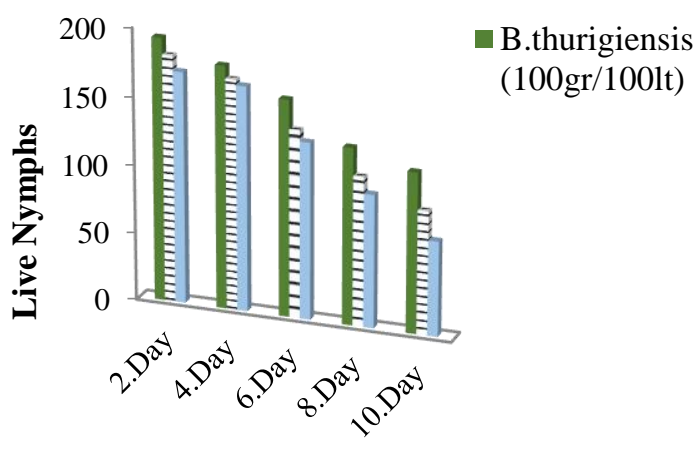

Control

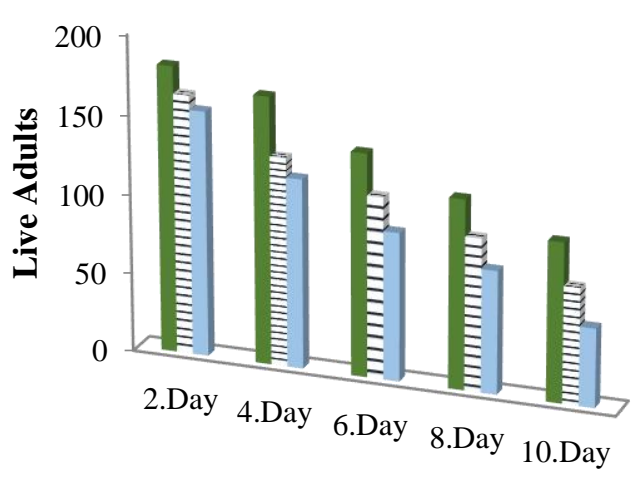

Control

Fig. 2: The effectiveness of different doses of Dipel $₫ D F$ BT on the nymphs and adults. 


\section{RESULT AND DISCUSSION}

Metcalfa pruinosa has become an important pest together with Ricana simulans in kiwi orchards in Eastern Black Sea Region in recent years. It decreases the quality and value of kiwi with the harms it causes in kiwi orchards. It was observed that the most frequently preferred host of this pest is the kiwi plant. In the study conducted by Guncan [18], the harms of $M$. pruinosa in kiwi orchards in Ordu and its surroundings were reported. It was reported in previous studies that the primary host of it was kiwi plant in Italy, France and Greece [19, 20].

In foreign countries, Neodryinus typhlocybae (Ashmead) (Hymenoptera: Dryinidae), which are one of the most important natural enemies of the Flatidae species, and various insecticides were used to control M. pruinosa in the biological fight [21]. No strategies have been developed so far in our country against this harmful species. The tea and kiwi areas are very close to each other in the region. The use of synthetic insecticides has been banned in and around the tea cultivation areas. This made it compulsory to search for the possibility of using plant-based natural pesticides, bioinsecticides and microbial compounds instead of synthetic pesticides. In this study, two different biopesticides were used in in vitro medium and the results were evaluated.

As a result of the trials, according to the results of the Homogeneity Group Test (Duncan Test, $\mathrm{P}=0.05$ ), which shows the effect of the biopesticides and their doses on the nymphs of M.pruinosa, there are no significant differences between the $150 \mathrm{ml} / 100 \mathrm{lt}$ dose and $300 \mathrm{ml} / 1001 \mathrm{lt}$ doses of Pyrethrum; and again, no differences were detected between the $600 \mathrm{ml} / 100 \mathrm{lt}$ dose of Pyrethrum and the 100gr/100lt dose of Dipel DF. It was also observed in the study that the efficacies of all the doses of Dipel DF were similar. According to the Homogeneity Group Test (Duncan Test, $\mathrm{P}=0.05$ ), which shows the effect of the applied biopesticides on the adults of Metcalfa pruinosa, the $150 \mathrm{ml} / 1001 \mathrm{t}$ dose of Pyrethrum was found to be different from the other doses. There were no differences between the efficacies of the $300 \mathrm{ml} / 100 \mathrm{lt}$ dose of Pyrethrum and the $100 \mathrm{gr} / 100 \mathrm{lt}$ dose of Bacillus thuringiensis; and again, there were no significant differences between the $300 \mathrm{gr} / 100 \mathrm{lt}$ and $500 \mathrm{gr} / 100 \mathrm{lt}$ dose of Bacillus thuringiensis and $500 \mathrm{gr} / 100 \mathrm{lt}$ dose of Bacillus thuringiensis and $300 \mathrm{ml} / 100 \mathrm{lt}$ dose of Pyrethrum. A biopesticide application was tried in the region previously against Ricania simulans, and it was reported that Spinosad (35 $\mathrm{ml} / 100 \mathrm{lt}$ ) was effective at a rate of $71,2-78,7 \%$ against the nymphs; and Nemazal $(400 \mathrm{ml} / 1001 \mathrm{t})$ was effective in biological terms at a rate of 30\%. [22]. As a result of the biopesticide applications, the lethal effect of Pyrethrum on the nymphs of M.pruinosa was found to be between
$49,5 \%$ and $72,5 \%$; and the lethal effect of it on the adults was found to be between $55,4 \%$ and $80 \%$. In Dipel DF, these rates were found to be $40,8 \%$ and $65 \%$ in nymphs, and $49,5 \%$ and $75 \%$ in adults.

As a result, in the present study, it was observed that both pesticides were effective on the nymphs and adults of M.pruinosa. The nymphs of M.pruinosa were influenced more by the applied biopesticides. The field research of these biopesticides must be well investigated before they are presented for active use.

\section{REFERENCES}

[1] Girolami V., Conte, L., Camporese, P., Benuzzi, M., Martir G.R. \& Dradi, D. (1996) Possibilita di controllo biologico della Metcalfa pruinosa". Informatore Agrario, 52:25.

[2] Vlad, M. \& Grozea, I. (2016) Host Plant Species of the Cicada Metcalfa Pruinosa in Romania. Bulletin UASVM series Agriculture 73:(1).

[3] Strauss G. (2010) Pest risk analysis of Metcalfa pruinosa in Austria. Journal of Pest Science, 83: 381390.

[4] Preda C. \& Skolka, M. (2009) First record of a new alien invasive species in Constanta - Metcalfa pruinosa (Homoptera:Fulgoroidea). In: Paltineanu C. (Ed.) Lucrarile Simpozionului Mediul şi agricultura in regiunile aride; Prima editie. Bucureşti. Estfalia, pp. 141-146.

[5] Trenchev G., Ivanova, I., Nikolov, P. \& Trencheva, K. (2007) Metcalfa pruinosa (Say, 1830) (Homoptera, Flatidae) a species new to the Bulgarian fauna. Plant Science, 44 (3): 195-198.

[6] Karsavuran, Y.\& Güçlü, S. (2004) A new pest for Turkey, Metcalfa pruinosa (Say, 1830) (Homoptera: Flatidae). Türkiye Entomoloji Dergisi, 28 (3): 209212.

[7] Lucchi, A. \& Santini, L. (2002) Aspetti fisiologici e morfo-funzionali in Metcalfa pruinosa (Hom.: Fulgoroidea) con riferimento agli effetti prodotti sulle produzioni agricole e sulle alberature ornamentali. Atti della Accademia Nazionale Italiana di Entomologia Rendiconti, 49: 131-147.

[8] Wilson, S.W. \& Lucchi, A. (2007) Feeding activity of the flatid planthopper Metcalfa pruinosa (Hemiptera: Fulgoroidea). Journal of the Kansas Entomological Society, 80 (2): 175-178.

[9] Grozea I., Gogan, A., Virteiu, MA., Grozea, A., Ramona, S., Molnar, L., Carabet, A. \& Dinnesen, S. (2011) Metcalfa pruinosa Say (insecta: homoptera: flatidae): A new pest in Romania. African Journal of Agricultural Research Vol. 6 (27), pp. 5870-5877.

[10] Wilson S. W. \& Lucchi, A. (2001) Distribution and ecology of Metcalfa pruinosa and associated 
planthoppers in North America (Homoptera: Fulgoroidea). Atti della Accademia Nazionale Italiana di Entomologia, Rendiconti, 49:121-130.

[11] Kahrer A. (2005) Introduction and possible spread of the planthopper Metcalfa pruinosa in Austria. Symposium Proceedings No. 81, Plant protection and Plant Health in Europe, introduction and spread of invasive species, helt at Humboldt University, Berlin, Germany. British Crop Protection Council, Alton, UK, pp. 133-134.

[12] Wilson, S.W. \& Lucchi, A. (2000) Aspetti sistematici, corologici, ecologici. In: Lucchi A. (Ed.) La Metcalfa negli ecosistemi italiani. Agenzia Regionale per lo Sviluppo el'Innovazione nel settore Agricolo-forestale, Firenze, pp. 13-28.

[13] Güncan A. \& Durmuşoğlu, E. (2004) Bitkisel Kökenli Doğal Insektisitler Üzerine Bir Değerlendirme. Hasad dergisi, 20 (233): 26-32.

[14] Christensen, K.P. (1990) Dipel Technical Material (Bacillus thuringiensis var. kurstaki): Infectivity and Pathogenicity to Rainbow Trout (Oncorhynchus mykiss) during a 32-Day Static Renewal Test. Wareham, Massachusetts, Springborn Laboratories Inc., pp 1-57.

[15] Feitelson, J.S., Payne J. \& Kim, L. (1992) Bacillus thuringiensis: Insects and Beyond. Bio/Technology 10, 271-275.

[16] Martin, J.C. \& Bonneau, X. (2006) Bacillus thuringiensis, 30 Years of Control of Cluster Caterpillars. Phytoma, 590: 4-7.

[17] Shaukat, A., Yusuf, Z., Ghulam Muhammad, A. \& Farhat, N. (2010) Bacillus thuringiensis and Its Application in Agriculture. African Journal of Biotechnology Vol. 9 (14), pp. 2022-2031.

[18] Güncan, A., (2014) Türkiye'de Kivi bahçelerinde Yeni Bir zararlı Metcalfa pruinosa (Say, 1830) (Hemiptera: Flatidae). Akademik Ziraat Dergisi, 3 (1): 41-44, 2014.

[19] Greatti M. \& Girolami, V. (1994) Efficacia di soluzioni dilavanti nel controllo degli stadi giovanili di Metcalfa pruinosa (Say). L'Informatore Agrario, 50 (21): 77-79.

[20] Navrozidis, E., Zartaloudis, Z. \& Vartholomaiou, A. (2009) The appearance of Metcalfa pruinosa (Say) on kiwi culture and control efforts at Pierias prefecture". Italus Hortus, 16 (5): 240.

[21]Lauterer, P. (2002) Citrus flatid planthopper Metcalfa pruinosa (Hemiptera: Flatidae), a new pest of ornamental horticulture in the Czech Republic. Plant Protect. Sci., 38: 145-148.

[22] Ak, K., Güçlü, Ş. \& Sekban, R.A. (2013) New pest in East Black Sea Region, Ricania simulans (Walker, 1851) determining effectiveness of bio-pesticides with active substances of azadirachtin and spinosad against (Hemiptera: Ricaniidae). Journal of Agricultural Sciences Research, 6 (1): 10-14. 